\title{
Constraints on the salinity-oxygen isotope relationship in the central tropical Pacific Ocean
}

\author{
Jessica L. Conroy ${ }^{\mathrm{a}, \mathrm{b}, *}$, Kim M. Cobb $^{\mathrm{c}}$, Jean Lynch-Stieglitz ${ }^{\mathrm{c}}$, Pratigya J. Polissar ${ }^{\mathrm{d}}$ \\ a Department of Geology, University of Illinois Urbana-Champaign, United States \\ ${ }^{\mathrm{b}}$ Department of Plant Biology, University of Illinois Urbana-Champaign, United States \\ c School of Earth and Atmospheric Sciences, Georgia Institute of Technology, United States \\ d Lamont Doherty Earth Observatory, Columbia University, United States
}

\section{A R T I C L E I N F O}

\section{Article history:}

Received 25 November 2013

Received in revised form 11 February 2014

Accepted 11 February 2014

Available online 20 February 2014

\section{Keywords:}

Stable water isotope

Salinity

Paleoclimate

Tropical Pacific

\begin{abstract}
A B S T R A C T
Uncertainties surround the relationship between salinity and the stable isotopic composition of seawater, largely due to a dearth of modern seawater isotope data. Here we report $191 \mathrm{new}$, paired measurements of salinity and seawater oxygen isotopes $\left(\delta^{18} \mathrm{O}_{\mathrm{sw}}\right)$ taken from the central tropical Pacific in May 2012, from the surface to 4600 $\mathrm{m}$ depth. We observe significant correlations between $\delta^{18} \mathrm{O}_{\mathrm{sw}}$ and salinity across the study region, with slopes ranging from 0.23 to $0.31 \%$ /psu for the mixed layer, and $0.35-0.42 \%$ /psu for waters between the mixed layer and $500 \mathrm{~m}$ depth. When considering $\delta^{18} \mathrm{O}_{\mathrm{sw}}$-salinity across averages of individual water masses in the region, slopes range from 0.21 to $0.40 \%$ /psu, albeit with appreciable scatter. Surface salinity and $\delta^{18} \mathrm{O}_{\mathrm{sw}}$ data corresponding to the North Equatorial Countercurrent are significantly higher than previously observed, which we attribute to a weak westerly current and dry conditions in the region during the May 2012 cruise. Subsurface (80-500 m) salinity values from 2012 are significantly lower than corresponding values from pre-existing regional data, highlighting a different latitudinal sampling distribution, while subsurface $\delta^{18} \mathrm{O}_{\mathrm{sw}}$ is not significantly different. Thus, in May 2012, $\delta^{18} \mathrm{O}_{\mathrm{sw}}$ in this region could not be used to distinguish between subsurface water masses of different salinities. Unlike other regions where the surface 'freshwater endmember' is close to the $\delta^{18} \mathrm{O}$ value of regional precipitation, the freshwater endmember implied by our dataset $(-10.38 \%$ o) is consistent with a strong evaporative influence. Paired $\delta^{18} \mathrm{O}-\delta \mathrm{D}$ values of precipitation and surface seawaters have similar slopes (5.0, 5.1 ), and relatively low intercepts $(1.4,0.8)$ indicating isotopic variability in both reservoirs is also partly controlled by evaporation.
\end{abstract}

(c) 2014 Elsevier B.V. All rights reserved.

\section{Introduction}

Variations in tropical Pacific Ocean temperature and atmospheric circulation have large-scale impacts on global climate. As such, it is important to quantify tropical Pacific ocean-atmosphere variability across a range of timescales, through the generation and analysis of paleoclimate proxy records from this region. Many of the most important records of past climate variability from the tropical Pacific are based on proxies linked to the stable isotopic composition of seawater. In particular, carbonate records of $\delta^{18} \mathrm{O}$ derived from fossil corals and marine microfossils are key indicators of past changes in ocean temperature and salinity (e.g., Dunbar et al., 1994; Cole et al., 2000; Gagan et al., 2000; Lea et al., 2000; Tudhope et al., 2001; Koutavas et al., 2002; Stott et al., 2002; Cobb et al., 2003; Correge, 2006; Oppo et al., 2009; Thompson et al., 2011; Koutavas and Joanides, 2012; Cobb et al., 2013; Leech et al., 2013; McGregor et al., 2013). Given that both temperature

\footnotetext{
* Corresponding author at: Department of Geology, University of Illinois UrbanaChampaign, Champaign, IL 61820, United States.

E-mail address: jconro@illinois.edu (J.L. Conroy).
}

and the $\delta^{18} \mathrm{O}$ value of seawater $\left(\delta^{18} \mathrm{O}_{\mathrm{sw}}\right)$ contribute to carbonate $\delta^{18} \mathrm{O}$ variability, independent constraints on temperature derived from $\mathrm{Mg} / \mathrm{Ca}$ in foraminifera (Nurnberg et al., 1996; Lea et al., 1999; Elderfield and Ganssen, 2000) or Sr/Ca in corals (Alibert and McCulloch, 1997; Beck et al., 1997; Gagan et al., 1998; Nurhati et al., 2009; Nurhati et al., 2011) allow for the explicit reconstruction of $\delta^{18} \mathrm{O}_{s w}$ variability. Such estimates may provide information about past salinity, given the strong empirical relationship between the $\delta^{18} \mathrm{O}_{\mathrm{sw}}$ and salinity (Craig and Gordon, 1965b; Fairbanks et al., 1997).

$\delta^{18} \mathrm{O}_{\mathrm{sw}}$ variability is often interpreted in the context of hydroclimate variability as evaporation and precipitation affect both $\delta^{18} \mathrm{O}_{\text {sw }}$ and salinity (Fairbanks et al., 1997; LeGrande and Schmidt, 2006). However, recent work on the tropical Pacific salinity budget indicates that changes in salinity are controlled by a combination of surface forcing, advection, and vertical mixing (Hasson et al., 2013). The relative importance of each of these terms in shaping the spatiotemporal variability of $\delta^{18} \mathrm{O}_{\mathrm{sw}}$ remains uncertain. These factors, as well as the extra degree of freedom provided by the stable isotopic composition of precipitation may drive variability $\delta^{18} \mathrm{O}_{\mathrm{sw}}$-salinity relationship. Model simulations have already highlighted the $\delta^{18} \mathrm{O}_{\text {sw }}$-salinity relationship likely varies temporally 
(Schmidt, 1999; Oppo et al., 2007; Schmidt et al., 2007; LeGrande and Schmidt, 2011), yet how the real world $\delta^{18} \mathrm{O}_{\mathrm{sw}}$-salinity relationship varies on different timescales remains unknown. How well available $\delta^{18} \mathrm{O}_{\mathrm{sw}}$-salinity data approximate mean $\delta^{18} \mathrm{O}_{\mathrm{sw}}$-salinity conditions is also unclear, given that short, episodic seawater $\delta^{18} \mathrm{O}$ sampling efforts likely alias substantial seasonal and interannual variability (Abe et al., 2009).

Currently, there is a dearth of $\delta^{18} \mathrm{O}_{\text {sw }}$ data from the tropical Pacific, which hinders our understanding of these potential complexities of the $\delta^{18} \mathrm{O}_{\mathrm{sw}}$-salinity relationship. Here we present 191 new, paired salinity- $\delta{ }^{18} \mathrm{O}_{\mathrm{sw}}$ values sampled in the central tropical Pacific in May 2012. These new data more than double the number of stable isotope observations in the central tropical Pacific, and more than triple the number of observations from the subsurface and deep ocean of this region. Although we are adding substantially to the $\delta^{18} \mathrm{O}_{\mathrm{sw}}$ database with these new data, our new dataset still represents only three weeks, and is thus subject to the temporal biases inherent in most $\delta^{18} \mathrm{O}_{\mathrm{sw}}$ data, which tend to be collected over short periods of time. We present the new data in the subsequent sections, investigate the $\delta^{18} \mathrm{O}_{\mathrm{sw}}$-salinity relationship across different depths and water masses, and compare the new dataset to previous observations from the region.

\section{Materials and methodology}

Seawater and rain samples for water isotope analysis $(\mathrm{N}=177$, $\mathrm{N}=6$ ) were taken from May 2 to May 23, 2012, during cruise MGL08-12 to the Line Islands Ridge. The sampling range encompasses $-0.22^{\circ} \mathrm{S}$ to $20.8^{\circ} \mathrm{N}, 161.5^{\circ} \mathrm{W}-156.0^{\circ} \mathrm{W}$, with the majority of samples from south of $10^{\circ} \mathrm{N}$ (Fig. 1). Additional surface seawater $(\mathrm{N}=14)$ and daily rain samples $(\mathrm{N}=10)$ were taken at Kiritimati during a landbased field expedition from May 16 to May 30, 2012. Shipboard and island rain samples were collected daily in a separatory funnel filled with a layer of mineral oil to prevent evaporation. Cruise seawater samples were taken from an uncontaminated seawater intake line $\sim 3 \mathrm{~m}$ below the surface and from 10-liter niskin bottles attached to a 24position rosette. The cruise salinity values are derived from a SBE-21 SEACAT Thermosalinigraph installed in the seawater intake line, and an SBE 9/11 plus V5.1 g CTD attached to the 24-position rosette. Salinity samples from Kiritimati were collected in $60 \mathrm{~mL}$ amberglass bottles simultaneously with seawater samples for isotope analysis, and were measured with a Mettler Toledo conductivity meter $( \pm 0.2$ psu precision), maintaining a constant sample temperature of $25^{\circ} \mathrm{C}$ in a dry bead heat block.

Stable isotope samples were sealed in $3.5 \mathrm{ml}$ crimp-top vials with butyl rubber stoppers and aluminum seals. Both seawater and precipitation $\delta^{18} \mathrm{O}$ and $\delta \mathrm{D}$ values were measured at Georgia Institute of Technology on a Picarro L1102-I water isotope analyzer. Samples were calibrated using three internal water standards $\left(\delta^{18} \mathrm{O}-16.49,-4.84\right.$, $0.93 \%$, $\delta \mathrm{D}-98.3 \%$, $-27.5 \%$, $-27.0 \%$ ) analyzed at the beginning and end of each 45-sample run (Moerman et al., 2013). These internal standards, are calibrated against NIST-VSMOW, NIST-GISP, and NISTSLAP. Instrument drift was assessed with an internal standard measured after every ninth sample. Each rainwater sample was measured three times. Coefficients that correct for instrument memory of the previous sample were applied to the rainwater data after measurement. For seawater samples, changes in memory with the addition of salts to the instrument precluded using memory coefficients. Instead, we measured each sample six times and averaged the last three values for each sample. Long-term instrument reproducibility is $\pm 0.1 \%$ ofor $\delta^{18} \mathrm{O}$ and $\pm 0.8 \%$ 。 for $\delta \mathrm{D}(1 \sigma)$. Data are reported as \% VSMOW. All seawater data will be archived on the Goddard Institute for Space Studies (GISS) global seawater oxygen-18 database (http://data.giss.nasa.gov/ o18data/) (Schmidt et al., 1999), and all precipitation isotope data will be archived on the Global Network of Isotopes in Precipitation (GNIP) database (IAEA/WMO, 2006).

$\delta^{18} \mathrm{O}_{\text {sw }}$ and salinity values from May 2012 water samples are compared to 78 paired $\delta^{18} \mathrm{O}_{\text {sw }}$ and salinity values archived in the GISS global seawater oxygen-18 database (Schmidt et al., 1999). These data are from $5^{\circ} \mathrm{S}-20^{\circ} \mathrm{N}, 175^{\circ} \mathrm{W}-140^{\circ} \mathrm{W}$, a region that expands beyond, but is centered on, the area in which the new data were collected. Central tropical Pacific $\delta^{18} \mathrm{O}_{\mathrm{sw}}$ and salinity values include data from JanuaryFebruary 1991 ( $\mathrm{N}=60$ ) (Laube-Le'Enfant, 1996), data of unknown month and year $(\mathrm{N}=12)$ from the mid 20th century (Epstein and Mayeda, 1953; Craig and Gordon, 1965a), and November-December 1973 data $(\mathrm{N}=6)$ from the Geochemical Open Sections Study (GEOSECS) database (Ostlund et al., 1987). This combined dataset is biased toward January and February 1991, as the majority of the data come from Laube-Le'Enfant (1996). Daily precipitation stable isotope values are compared to monthly $\delta^{18} \mathrm{O}$ and $\delta \mathrm{D}$ values $(\mathrm{N}=23,1962-$ 1964) from Kiritimati available from GNIP (IAEA/WMO, 2006).

\section{Results and discussion}

\subsection{Paired $\delta^{18} \mathrm{O}_{s w}$ and salinity observations}

Ninety-five seawater samples are from the surface mixed layer, estimated at $75 \mathrm{~m}$ from CTD casts between the equator and $10^{\circ} \mathrm{N}$. May 2012 surface, mixed layer $\delta^{18} \mathrm{O}_{\mathrm{sw}}$ values range from 0.22 to $0.68 \%$ (Figs. 1,2 ) with a mean of $0.47 \pm 0.12 \%$ o ( $1 \sigma$ standard deviation). As apparent in Fig. 2, the mean surface $\delta^{18} \mathrm{O}_{\mathrm{sw}}$ value from off the coast of Kiritimati $(0.38 \pm 0.07 \%)$ is slightly fresher than the mean $\delta^{18} \mathrm{O}_{\mathrm{sw}}$ value from the open ocean at nearby latitudes $(0.56 \pm 0.08 \%$ o). This may be due to submonthly variability - Kiritimati experienced more precipitation from May 15-May 30 relative to earlier in the month when the cruise samples were taken. Or, potential groundwater flux may be driving lower salinity and $\delta^{18} \mathrm{O}_{\mathrm{sw}}$ values near the island shore. Given this potential bias, we exclude the Kiritimati seawater measurements from regression analyses.
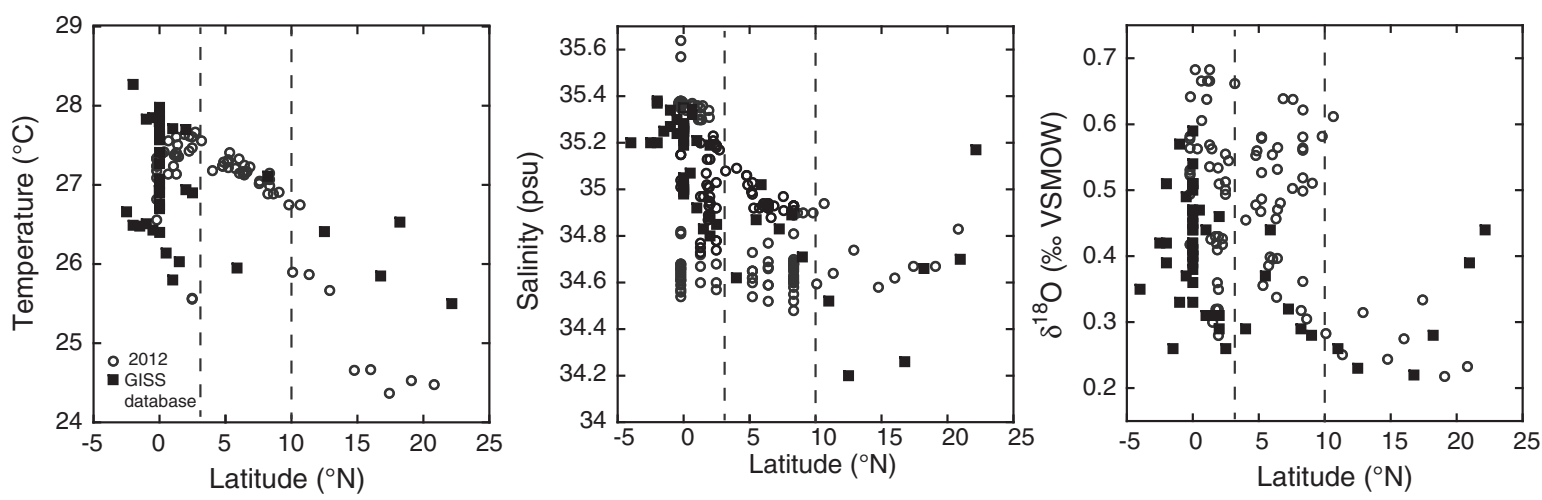

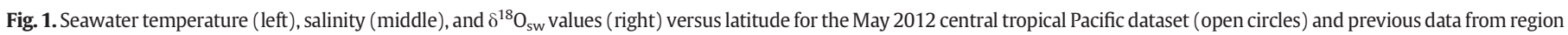
archived in GISS database (squares). Dashed lines, from south to north indicate SEC, NECC, and NEC regions. 
A

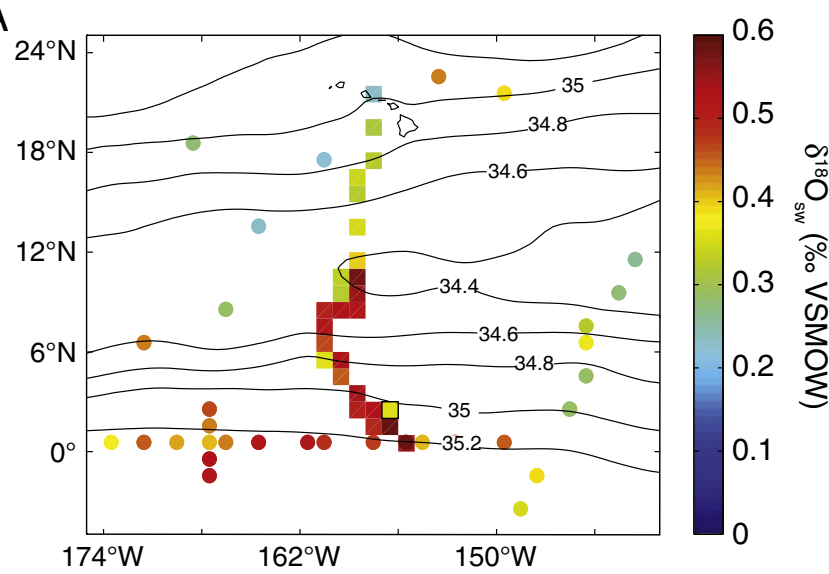

$\mathrm{B}$

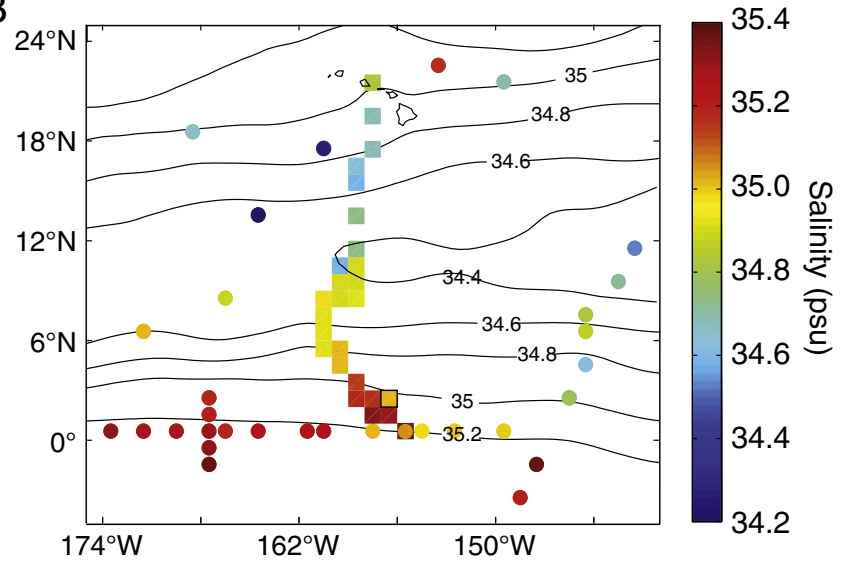

Fig. 2. Map of surface $\delta^{18} \mathrm{O}_{\mathrm{sw}}$ values (A) and paired salinity measurements (B) taken during May 2012 Line Islands cruise (squares). Black outlined square denotes nearshore island samples from Kiritimati. Values are compared to $\delta^{18} \mathrm{O}_{\mathrm{sw}}$ and salinity data from previous samples archived in GISS $\delta^{18} \mathrm{O}_{\mathrm{sw}}$ database (circles). Data are averaged into $1^{\circ} \times 1^{\circ}$ grid cells. Black contours indicate mean annual salinity climatology values from MIMOC database (Johnson et al., 2012).

Fifty-five seawater isotope samples are from the subsurface (75-500 $\mathrm{m})$, and 41 seawater isotope samples are from the deep ocean $(>800 \mathrm{~m})$. Subsurface $\delta^{18} \mathrm{O}_{\mathrm{sw}}$ values have a larger range, from 0.02 to $0.72 \%$, with a mean of $0.35 \pm 0.15 \%$ 。 (Figs. 3,4 ). The highest $\delta^{18} \mathrm{O}_{s w}$ values in the dataset occur in the subsurface near the equator at $100 \mathrm{~m}$ depth. Pacific Deep Water (PDW) $\delta^{18} \mathrm{O}_{\mathrm{sw}}$ values from 800 to $4600 \mathrm{~m}$ depth are the lowest of the dataset, ranging from -0.28 to $0.18 \%$ o with a mean of $-0.01 \pm 0.11 \%$.
There is a significant relationship between salinity and $\delta^{18} \mathrm{O}_{\mathrm{sw}}$ values across the May 2012 dataset. In order to reduce analytical and environmental noise, we present the raw data averaged into 0.05 psu salinity bins in Fig. 4. In the mixed layer, salinity and $\delta^{18} \mathrm{O}_{\mathrm{sw}}$ are strongly correlated, with a linear $\delta^{18} \mathrm{O}_{\mathrm{sw}}$-salinity relationship defined by a slope of $0.31 \%$ psu $(0.22$ to $0.40,2 \sigma)$ and an intercept of $-10.38 \%$ o $(-13.43$ to $-7.33 \%, 2 \sigma)$. The $\delta^{18} \mathrm{O}_{\mathrm{sw}}$-salinity relationship in the subsurface, with a slope of $0.42 \% / \mathrm{psu}(0.34$ to $0.50,2 \sigma)$ and intercept of $-14.24 \%$ o ( -17.17 to $-11.31 \%$, $2 \sigma$ ), is not significantly different than the surface $\delta^{18} \mathrm{O}_{s w}$-salinity relationship; much of the data from the surface and subsurface overlap (Fig. 4). PDW is defined by fewer binned datapoints, as salinity is more uniform, only spanning $0.3 \mathrm{psu}$ at these depths; there is no significant relationship between $\delta^{18} \mathrm{O}_{\mathrm{sw}}$ and salinity below $500 \mathrm{~m}$.

\subsection{Temporal variability: May 2012 versus previous data}

Previous $\delta^{18} \mathrm{O}_{\mathrm{sw}}$-salinity values from the central tropical Pacific come from different years and months. However, these data, which may have seasonal, interannual, or decadal biases, represent our best estimation of the mean $\delta^{18} \mathrm{O}_{s w}$-salinity relationship across a large, oceanographically complex region. In the following sections, we compare the May $2012 \delta^{18} \mathrm{O}_{\mathrm{sw}}$ and salinity values to the previous central tropical Pacific $\delta^{18} \mathrm{O}_{\mathrm{sw}}$-salinity data, which are biased toward January-February 1991. We note that there may also be an interannual as well as a seasonal bias in the data. NINO3.4 for May 2012 was $0.05{ }^{\circ} \mathrm{C}$ - near neutral. In January-February 1991 , the average NINO3.4 value was $0.45^{\circ} \mathrm{C}$ (Smith et al., 2008).

\subsection{Surface $\delta^{18} O_{s w}$ and salinity}

A Wilcoxon rank-sum test indicates that median mixed layer $\delta^{18} \mathrm{O}_{\mathrm{sw}}$ and salinity values from earlier data $(0.44 \%, 35.20 \mathrm{psu})$ and 2012 (0.49\%, $34.97 \mathrm{psu})$, are not significantly different at the $99 \%$ confidence level ( $p=0.013, p=0.031$, respectively). Although the linear $\delta^{18} \mathrm{O}_{\mathrm{sw}}$-salinity relationship from the previous surface data has a lower slope $(0.23 \% / \mathrm{psu}, 0.17-0.30 \% / \mathrm{psu}, 2 \sigma)$ and intercept $(-7.82 \%,-10.10$ to $-5.53 \%, 2 \sigma)$, the values are not significantly different from the slope and intercept of the May $2012 \delta^{18} \mathrm{O}_{\mathrm{sw}}$-salinity data (Fig. 4). These results support the integrity of both the more recent cavity ringdown spectroscopy (CRDS) and previous traditional mass spectrometry measurements from the region as accurate to within their reported uncertainties. They also suggest that these median, regional values are not substantially biased by seasonal or interannual variability.

To assess surface spatial patterns in the new surface $\delta^{18} \mathrm{O}_{\text {sw }}$ data, we average the surface data into $1^{\circ} \times 1^{\circ}$ grids (Fig. 2). Spatial variation in $\delta^{18} \mathrm{O}_{\text {sw }}$ at the surface is prominent, with lower values $(0.3-0.4 \%$ o) to
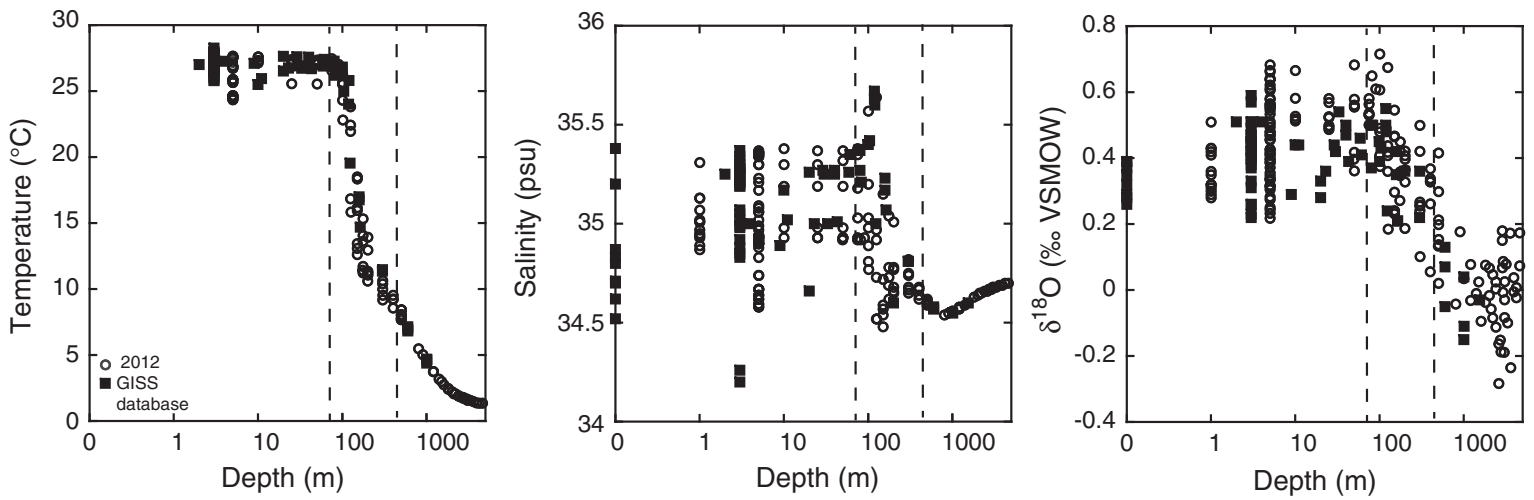

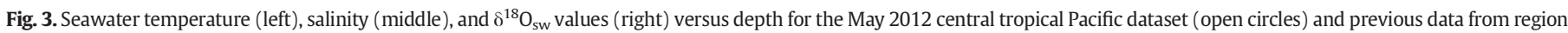
archived in GISS database (squares). Dashed lines indicate surface (0-75 m), subsurface (80-500 m) and deep (>500 m) regions. 
A

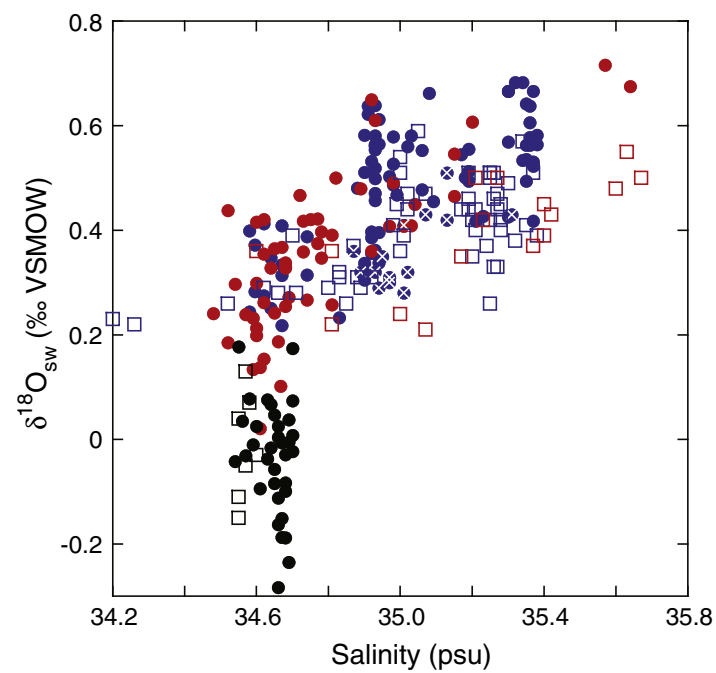

$-20120-75 \mathrm{~m}\left(\delta^{18} \mathrm{O}_{\mathrm{sw}}=-10.38+0.31\right.$ salinity $\left.\mathrm{r}=0.91\right)$ $-201280-500 \mathrm{~m}\left(\delta^{18} \mathrm{O}_{\mathrm{sw}}=-14.38+0.42\right.$ salinity $\left.\mathrm{r}=0.94\right)$ $2012>500 \mathrm{~m}$ - CISS $0-75 \mathrm{~m}\left(\delta^{18} \mathrm{O}=-7.82+0.23\right.$ salinity $\left.r=0.88\right)$ - - GISS $80-500 \mathrm{~m}\left(\delta^{18} \mathrm{O}_{\mathrm{sw}}=-11.83+0.35\right.$ salinity $\left.r=0.83\right)$ B $0.8 \quad \square \quad$ GISS $>500 m$

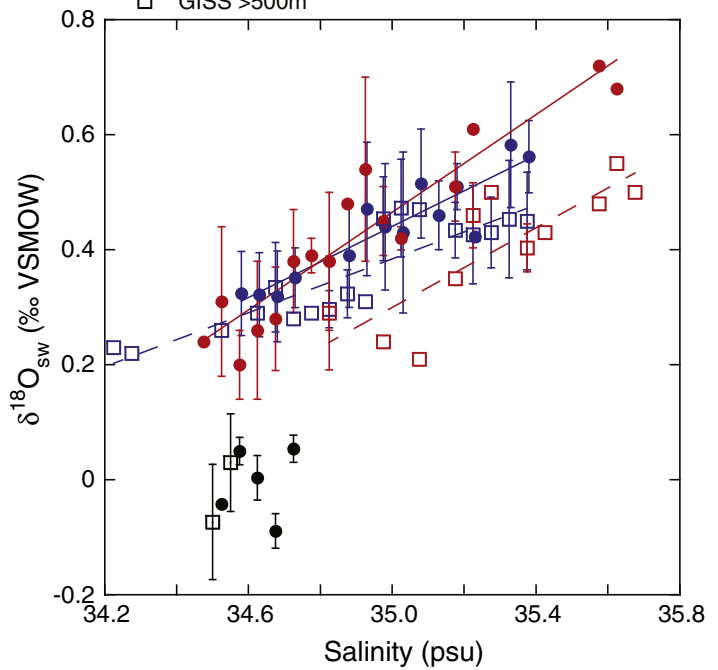

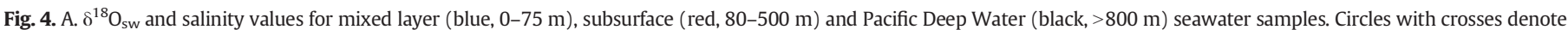

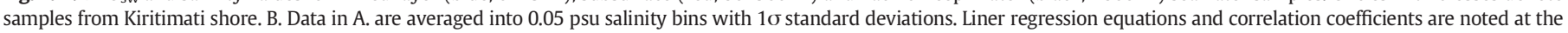
top. In both plots, May 2012 samples (circles) are compared to previous values archived in $\mathrm{GISS} \delta^{18} \mathrm{O}_{\mathrm{sw}}$ database (squares).

the north and higher values $(0.5-0.6 \%)$ to the south of $10^{\circ} \mathrm{N}$ in May 2012 (Fig. 2A). A sharp transition at this latitude is also observed in the May 2012 salinity measurements (Fig. 2B). The location of the abrupt latitudinal shift from lower to higher mixed layer $\delta^{18} \mathrm{O}_{\mathrm{sw}}$ values occurs closer to the equator, at $6^{\circ} \mathrm{N}$, in the older dataset. Additionally, the older dataset features two low $\delta^{18} \mathrm{O}_{\text {sw }}$ /salinity values at $13^{\circ}$ and $17^{\circ} \mathrm{N}$, which appear to be outliers relative to all other regional data (Figs. 1, 2, 4). These data come from December 1973, a period of La Niña conditions in the NINO3.4 region, following the 1972/73 El Niño. The anomalously low $\delta^{18} \mathrm{O}_{\mathrm{sw}}$ and salinity values may be related to anomalously high precipitation: November 1973 was a relatively wet month at nearby Johnston Atoll $\left(16.7^{\circ} \mathrm{N}, 169.5^{\circ} \mathrm{W}\right)$, with $188 \mathrm{~mm}$ of precipitation recorded relative to the $97 \mathrm{~mm}$ long-term November mean (Peterson and Vose, 1997).

\subsection{Subsurface $\delta^{18} \mathrm{O}_{\text {sw }}$-salinity}

Fig. 4 indicates substantial overlap between May $2012 \delta^{18} \mathrm{O}_{\mathrm{sw}}$-salinity values in the subsurface $(80-500 \mathrm{~m})$ and in the mixed layer $(0-75 \mathrm{~m})$. Vertical mixing, including upwelling and subduction, may impart surface and subsurface similarity in salinity, and likely $\delta^{18} \mathrm{O}_{\mathrm{sw}}$, in this region (Hanawa and Talley, 2001; Hasson et al., 2013). However, the higher slope and lower intercept of the subsurface waters are also similar to surface seawater slopes and intercepts from the Northern and Southern Pacific (LeGrande and Schmidt, 2006), as the subsurface comprises water that has been advected equatorward from subtropical gyres (Johnson et al., 2002; Liu et al., 1994; McCreary and Lu, 1994).

The median subsurface $\delta^{18} \mathrm{O}_{\mathrm{sw}}$ value from May $2012(0.36 \%$ $\mathrm{N}=54)$ is not significantly different from the median $\delta^{18} \mathrm{O}_{\text {sw }}$ value of the previously collected subsurface samples $(0.37 \%, p=0.949$ $\mathrm{N}=18$ ). However, the median of the earlier salinity values (35.19 psu) is significantly higher compared to the median May 2012 salinity (34.69 psu, $\mathrm{p}=0.003$ ). This is also apparent in the cluster of May 2012 subsurface salinity values between 34.5 and 34.75 in Fig 3B. These values plot below much of the earlier subsurface salinity data, particularly between 80 and $200 \mathrm{~m}$ depth. Yet Fig. $3 \mathrm{C}$ reveals more overlap between $\delta^{18} \mathrm{O}_{\mathrm{sw}}$ in the current and previous observations. Fresher values in May 2012 are likely due to latitudinal sampling biases, as previous subsurface data in this region was confined to the equator, whereas the 2012 data are from $0^{\circ}$ to $10^{\circ} \mathrm{N}$. However, these fresher values are not manifested as substantially lower subsurface $\delta^{18} \mathrm{O}_{\mathrm{sw}}$, suggesting that $\delta^{18} \mathrm{O}_{\mathrm{sw}}$ could not discern fresher Northern Hemisphere subsurface waters from more saline Southern Hemisphere subsurface waters, at least in May 2012 versus Jan-Feb 1991 . The higher salinity values but similar $\delta^{18} \mathrm{O}_{s w}$ in the earlier subsurface data produce a lower $\delta^{18} \mathrm{O}_{\mathrm{sw}}$-salinity slope, although the slope and intercept of the subsurface $\delta^{18} \mathrm{O}_{\mathrm{sw}}$-salinity from the earlier subsurface data are still not significantly different from May 2012.

\section{5. $\delta^{18} \mathrm{O}_{s w}$-salinity across water masses}

The strong $\delta^{18} \mathrm{O}_{\mathrm{sw}}$-salinity relationships in the surface and subsurface of the central tropical Pacific cut across five major tropical Pacific ocean currents with distinctive water mass properties (Johnson et al., 2002). Three major surface currents, the easterly North Equatorial Current (NEC), the westerly North Equatorial Countercurrent (NECC), and the easterly South Equatorial Current (SEC) advect water across the central tropical Pacific. The SEC and NEC transport more saline waters, whereas the NECC transports relatively fresher waters from the west Pacific warm pool (Hasson et al., 2013). The subsurface is defined by two major currents, the westerly Equatorial Undercurrent (EUC), from $\sim 75$ m-200 m depth, and the Equatorial Intermediate Current (EIC), which lies below the EUC at 200-500 m depth (Johnson et al., 2002). The EIC is easterly, but may shift directions seasonally (Marin et al., 2010). Another key water mass in the region is ' $13^{\circ} \mathrm{C}$ water' which advects across the tropical Pacific Basin from west to east (Tsuchiya et al., 1990; Toggweiler and Dixon, 1991; Benway and Mix, 2004). Fig. 5 shows average $\delta^{18} \mathrm{O}_{\mathrm{sw}}$ and salinity values in each of these currents and the $13{ }^{\circ} \mathrm{C}$ water mass, along with $1 \sigma$ standard deviations. Values are plotted for both the May 2012 and the archived data.

There is a consistent $\delta^{18} \mathrm{O}_{\mathrm{sw}}$-salinity relationship across these water masses in the surface and subsurface, with a slope of $0.40 \%$ /psu $(0.22-$ $0.582 \sigma)$, and an intercept of $-13.5 \%$ o $(-19.9$ to $-7.1,2 \sigma)$, in May 2012. Fig. 5 also shows the same current and water mass $\delta^{18} \mathrm{O}_{\mathrm{sw}}$-salinity values calculated from previous $\delta^{18} \mathrm{O}_{\mathrm{sw}}$-salinity data in the region. The slope is lower $(0.21 \% / \mathrm{psu},-0.01-0.42,2 \sigma)$ and the intercept is higher 


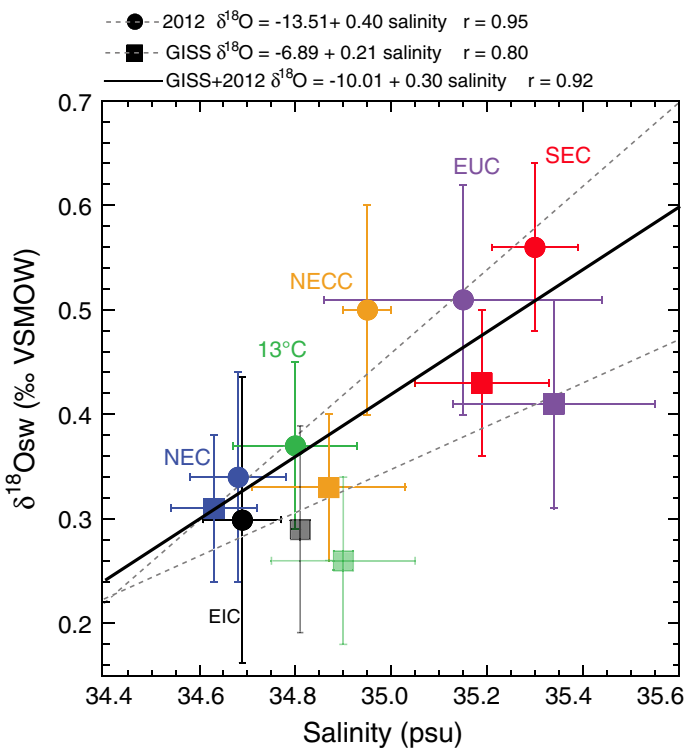

Fig. 5. Average $\delta^{18} \mathrm{O}_{\mathrm{sw}}$ and salinity values, with $1 \sigma$ standard deviations, in major ocean currents across sampling region. Linear regression curves (gray dashed lines) and equations are shown for both May 2012 data (circles), and previous values archived in GISS $\delta^{18} \mathrm{O}_{\mathrm{sw}}$ database (squares). Linear regression for all data averaged together is plotted in black line. Current/water mass abbreviations given in text. Light gray, green points are averaged from less than 3 individual data points, and are considered less robust.

( $-6.9 \%$, -14.5 to 0.70 ), in the earlier data although they are not significantly different than May 2012 values.

In May 2012, the SEC had the highest $\delta^{18} \mathrm{O}_{\text {sw }}$ and salinity values, followed by the EUC and NECC, whereas the NEC, EIC, and $13^{\circ} \mathrm{C}$ water had the lowest $\delta^{18} \mathrm{O}_{s w}$ and salinity values. The value of the $13^{\circ} \mathrm{C}$ water mass is similar to $\delta^{18} \mathrm{O}_{\mathrm{sw}}$ and salinity values measured in the same water mass in the Panama Bight region (Benway and Mix, 2004). The EUC has the largest salinity standard deviation (and the highest raw $\delta^{18} \mathrm{O}_{\text {sw }}$ and salinity values), as it incorporates both more saline Southern Hemisphere $(\mathrm{SH})$ waters and relatively fresher Northern Hemisphere
$(\mathrm{NH})$ waters that have advected toward the equator (Johnson et al., 2002). However, the $\delta^{18} \mathrm{O}_{s w}$ standard deviation of the EUC (0.11\%) is not substantially higher than the $\delta^{18} \mathrm{O}_{\mathrm{sw}}$ standard deviation of the other currents $(0.08-0.14 \%$ ) and the instrumental precision $(0.10 \%$ ), suggesting $\delta^{18} \mathrm{O}_{s w}$ in the EUC may not track salinity as well as in other currents, as $\delta^{18} \mathrm{O}_{\text {sw }}$ cannot differentiate $\mathrm{NH}$ and $\mathrm{SH}$ subsurface waters of different salinities. Conversely the EIC, which falls near the NEC in salinity- $\delta{ }^{18} \mathrm{O}_{\mathrm{sw}}$ space, has the largest $\delta^{18} \mathrm{O}_{\mathrm{sw}}$ standard deviation $(0.14 \%$ ), but a relatively small salinity standard deviation. The ratio of the salinity to $\delta^{18} \mathrm{O}_{\text {sw }}$ standard deviation in the NECC is also lower, suggesting potential limitations on the interpretability of $\delta^{18} \mathrm{O}_{\mathrm{sw}}$ as salinity, at least using CDRS method with its standard precision of $\pm 0.10 \%$ o $(1 \sigma)$ for $\delta^{18} \mathrm{O}$.

In Fig. 5, the May 2012 NECC data show the largest difference compared to the 1991-biased data, especially in $\delta^{18} \mathrm{O}_{\mathrm{sw}}$ space, with more saline and higher (and more variable) $\delta^{18} \mathrm{O}_{\mathrm{sw}}$ values in May $2012 \mathrm{com}$ pared to the earlier data. This might be explained by anomalous surface currents in this region during the May 2012 cruise, when the region of typical NECC flow $\left(3-9^{\circ} \mathrm{N}\right)$ experienced easterly current anomalies, suggesting a weakened NECC at this time (Fig. 6). Additionally, there was anomalously low precipitation minus evaporation ( $\mathrm{P}-\mathrm{E}$ ) and a prominent high salinity anomaly in the region in May 2012. The higher $\delta^{18} \mathrm{O}_{\mathrm{sw}}$ values relative to salinity values in May 2012 may also be due to the additional kinetic effects of evaporation on the isotopic composition of seawater, imparting a larger signal in the isotopes relative to salinity. While these anomalies may explain the relatively higher $\delta^{18} \mathrm{O}_{\mathrm{sw}}$ values in the NECC in May 2012, we note that we cannot yet distinguish the relative contributions of advection, surface forcing, and vertical mixing to the isotope budget with the available data.

\subsection{Precipitation isotopes and the freshwater endmember}

Daily precipitation $\delta^{18} \mathrm{O}$ and $\delta \mathrm{D}$ values presented here include 10 samples from Kiritimati and 6 samples from cruise MGL12-08. The 10 daily rain samples from Kiritimati and 6 daily shipboard rain samples have $\delta^{18} \mathrm{O}$ values ranging from $-3.5 \%$ to $0.1 \%$ and $\delta \mathrm{D}$ values ranging from -18.4 to $3.1 \%$ (Table 1 ). Mean $\delta^{18} \mathrm{O}$ and $\delta \mathrm{D}$ values of daily precipitation are $-1.6 \pm 0.8 \%$ o $(1 \sigma)$ and $-4.2 \pm 5.6 \%$ o $(1 \sigma)$, respectively. The island and open ocean precipitation isotope values overlap, although
A

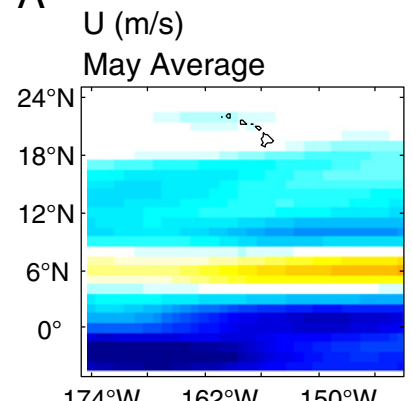

$174 \mathrm{~W}$

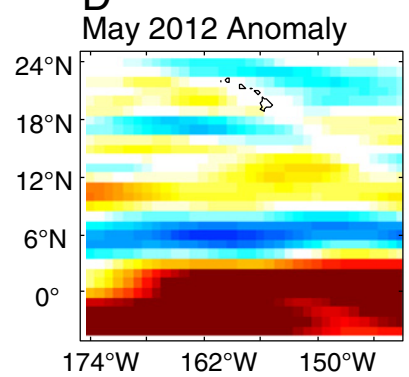

B
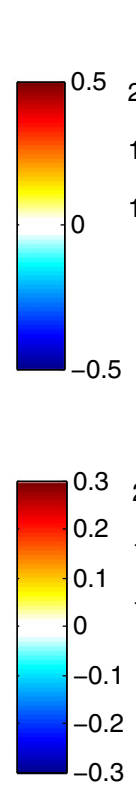

Salinity (kg/kg)

May Average

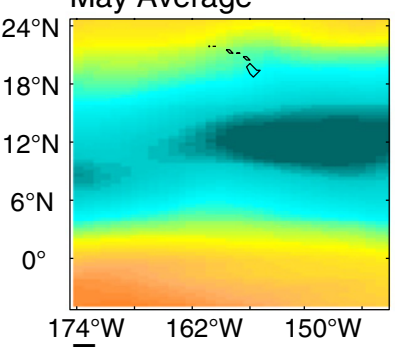

E

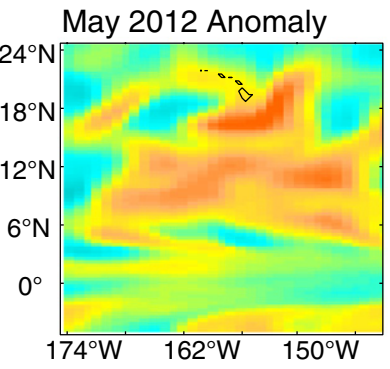

C

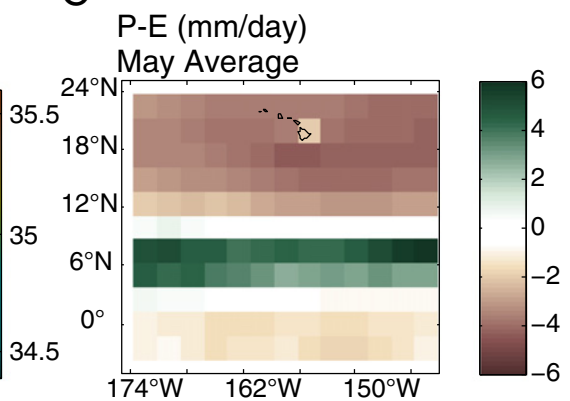

$\mathrm{F}$

May 2012 Anomaly
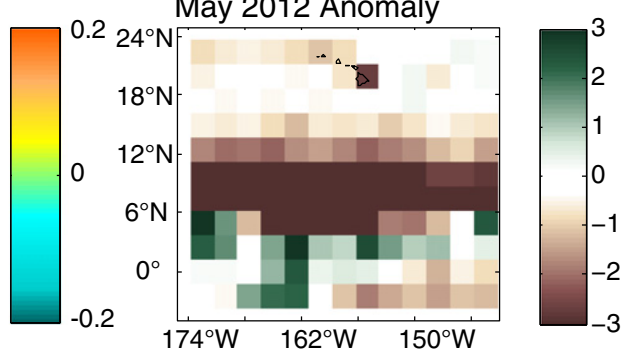

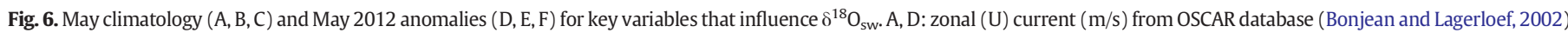
B, E: salinity ( $\mathrm{kg} / \mathrm{kg}$ ) from GODAS (Behringer et al., 1998), C, F: P - E (mm/day) from GPCPv2.2 (Adler et al., 2003) and WHOI oaFlux dataset (Yu and Weller, 2007). 
Table 1

Stable isotope values of daily precipitation samples from Kiritimati $\left(1.99^{\circ} \mathrm{N} 157.47^{\circ} \mathrm{W}\right)$ and Line Islands cruise. Latitude and longitude of cruise samples are listed as daily averages (prior to rain sample recovery).

\begin{tabular}{|c|c|c|c|c|}
\hline \multirow[t]{2}{*}{ Date } & \multirow[t]{2}{*}{ Sampling location } & \multirow{2}{*}{$\frac{\text { Amount }}{(\mathrm{mm} / \mathrm{day})}$} & \multirow{2}{*}{$\frac{\delta^{18} \mathrm{O}}{(\% \circ \mathrm{VSMOW})}$} & \multirow{2}{*}{$\frac{\delta \mathrm{D}}{(\% \circ \mathrm{VSMOW})}$} \\
\hline & & & & \\
\hline 5-May-2012 & $8.12^{\circ} \mathrm{N} 160.24^{\circ} \mathrm{W}$ & 0.19 & $-1.24 \pm 0.05$ & $-0.25 \pm 0.52$ \\
\hline 9-May-2012 & $4.29^{\circ} \mathrm{N} 159.84^{\circ} \mathrm{W}$ & 3.84 & $-2.62 \pm 0.06$ & $-12.26 \pm 0.10$ \\
\hline 11-May-2012 & $0.66^{\circ} \mathrm{N} 156.71^{\circ} \mathrm{W}$ & 2.34 & $-1.79 \pm 0.05$ & $-6.36 \pm 0.34$ \\
\hline 15-May-2012 & $1.80^{\circ} \mathrm{N} 158.09^{\circ} \mathrm{W}$ & 3.47 & $-1.63 \pm 0.11$ & $-3.57 \pm 0.53$ \\
\hline 17-May-2012 & Kiritimati & 0.26 & $0.06 \pm 0.01$ & $3.07 \pm 0.38$ \\
\hline 18-May-2012 & $4.79^{\circ} \mathrm{N} 160.04^{\circ} \mathrm{W}$ & 9.79 & $-2.22 \pm 0.03$ & $-7.98 \pm 0.32$ \\
\hline 18-May-2012 & Kiritimati & 12.47 & $-3.48 \pm 0.09$ & $-18.45 \pm 0.59$ \\
\hline 19-May-2012 & $5.20^{\circ} \mathrm{N} 160.43^{\circ} \mathrm{W}$ & 4.37 & $-1.45 \pm 0.04$ & $-2.75 \pm 0.33$ \\
\hline 21-May-2012 & Kiritimati & 0.53 & $-1.80 \pm 0.08$ & $-6.66 \pm 0.55$ \\
\hline 22-May-2012 & Kiritimati & 8.02 & $-1.66 \pm 0.14$ & $-5.31 \pm 0.19$ \\
\hline 23-May-2012 & Kiritimati & 6.22 & $-1.41 \pm 0.11$ & $-2.72 \pm 0.40$ \\
\hline 24-May-2012 & Kiritimati & 3.16 & $-1.23 \pm 0.04$ & $0.81 \pm 0.77$ \\
\hline 25-May-2012 & Kiritimati & 11.83 & $-1.92 \pm 0.07$ & $-5.52 \pm 0.31$ \\
\hline 26-May-2012 & Kiritimati & 0.08 & $-0.27 \pm 0.09$ & $2.90 \pm 1.09$ \\
\hline 27-May-2012 & Kiritimati & 2.56 & $-1.18 \pm 0.03$ & $-0.33 \pm 0.01$ \\
\hline 29-May-2012 & Kiritimati & 10.40 & $-1.51 \pm 0.04$ & $-2.39 \pm 0.17$ \\
\hline
\end{tabular}

the highest and lowest precipitation isotope values in the dataset are from Kiritimati. The daily precipitation data define a meteoric water line with a $\left(\delta \mathrm{D} / \delta^{18} \mathrm{O}\right.$ slope) of 6.5 and a d-excess value of $6 \%$.

Linear relationships between $\delta^{18} \mathrm{O}$ and salinity have been used to infer the $\delta^{18} \mathrm{O}$ value of a freshwater endmember, defined as the $\delta^{18} \mathrm{O}_{\mathrm{sw}}$ value when salinity equals zero (Delaygue et al., 2001; Benway and Mix, 2004; LeGrande and Schmidt, 2006; Abe et al., 2009; Munksgaard et al., 2012). In midlatitude and tropical regions, the freshwater endmember has been interpreted with respect to the $\delta^{18} \mathrm{O}$ of regional precipitation (Benway and Mix, 2004; LeGrande and Schmidt, 2006; Abe et al., 2009), river water (Munksgaard et al., 2012), or a combination of precipitation, evaporation, and runoff (Delaygue et al., 2001). In the Great Barrier Reef, the freshwater endmember $\delta^{18} \mathrm{O}$ and $\delta \mathrm{D}$ values were similar to the $\delta^{18} \mathrm{O}$ and $\delta \mathrm{D}$ values of local river water (Munksgaard et al., 2012). Over the Panama Bight region, the $\delta^{18} \mathrm{O}$ value of the freshwater endmember was found to be lower than most precipitation $\delta^{18} \mathrm{O}$ values from the region (Benway and Mix, 2004). This was interpreted as evidence that half of the freshwater forcing originates from infrequent, large convective events derived from a distilled vapor source that has crossed the Panama isthmus; regional runoff was concluded to be too small to contribute substantially to the endmember value (Benway and Mix, 2004). In the central tropical Pacific, the surface freshwater endmember $(-10.38 \%)$ is also much lower than daily precipitation $\delta^{18} \mathrm{O}$ values measured during the cruise period or monthly values from the GNIP database (Table 1, Fig. 7). As we currently have no evidence for highly depleted $(\sim 10 \%$ ) precipitation events in this region from the daily or monthly GNIP $\delta^{18} \mathrm{O}$ precipitation values, we cannot attribute the freshwater endmember solely to regional precipitation.

In the open ocean, without significant continental runoff, Delaygue et al., 2001 defined the surface freshwater endmember as a function of both precipitation and evaporation:

Intercept $=\frac{\delta^{18} \mathrm{OpP}-\delta^{18} \mathrm{OeE}}{\mathrm{P}-\mathrm{E}}$.

We calculate this value for the central tropical Pacific region represented by our isotope samples using May 2012 values for $\mathrm{P}$ and E, namely $1.29 \mathrm{~mm} /$ day (Adler et al., 2003) and $4.04 \mathrm{~mm} /$ day (Yu and Weller, 2007), respectively. These values are obtained by averaging values from the interpolated $1 \times 1^{\circ}$ boxes in Fig. 2 . We use the amount-weighted average of $\delta^{18} \mathrm{O}$ values from May $2012(-2.0 \%$, which is in close agreement to $\delta^{18} \mathrm{O}_{\mathrm{p}}$ values of $-2.2 \pm 0.5 \%$ from this region reported in Sayani et al. (2011)), and for $\delta^{18} \mathrm{O}_{e}$, we assume values ranging from -8 to $-12 \%$, corresponding to vapor in equilibrium with regional mean surface seawater $(0.47 \pm 0.12 \%$ o, allowing for additional

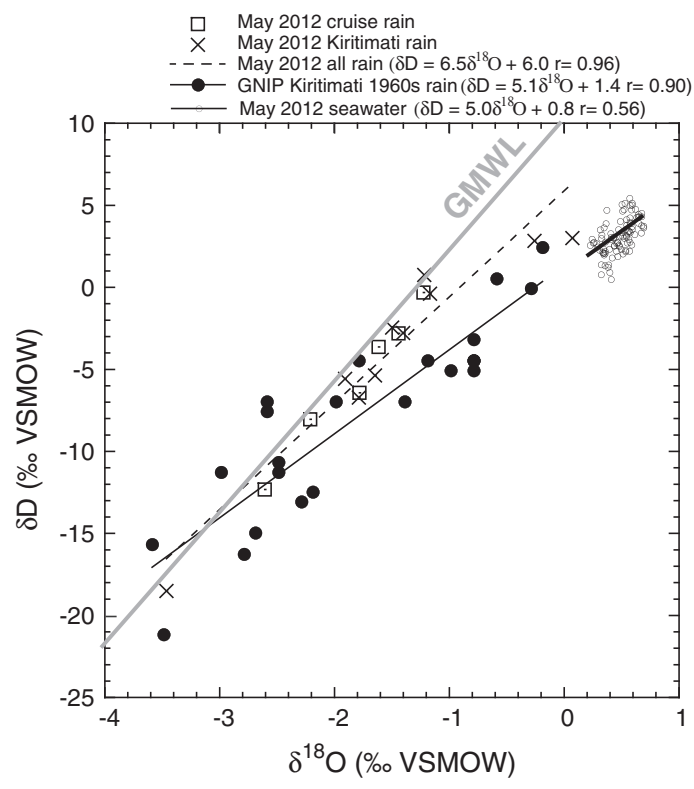

Fig. 7. Surface seawater and precipitation of the central tropical Pacific in $\delta^{18} \mathrm{O}-\delta \mathrm{D}$ space. Monthly GNIP $\delta^{18} \mathrm{O}$ values from Kiritimati are filled circles, daily Kiritimati precipitation $\delta^{18} \mathrm{O}$ values from 2012 are plotted as crosses, and daily cruise precipitation $\delta^{18} \mathrm{O}$ values from 2012 are plotted as open squares. Linear regression lines are plotted with equations for daily (combined Kiritimati and cruise samples) and monthly GNIP $\delta^{18} \mathrm{O}-\delta \mathrm{D}$ precipitation values. The global meteoric water line (GMWL) is plotted as solid gray line. Surface seawater $\delta^{18} \mathrm{O}$ and $\delta \mathrm{D}$ values from May 2012 are plotted as open circles with a linear regression line.

depletion (for relative humidity as low as 75\%) due to kinetic fractionation effects (Gonfiantini, 1986; Majoube, 1971). Note that in Eq. 1, the $E$ flux is subtracted from $P$, so negative vapor values will lead to an enrichment of the seawater, as expected. Using these values, we obtain intercepts ranging from $-10.8 \%$ to $-16.7 \%$ at $S=0$. This range of values overlaps the observed freshwater endmember of $-10.38 \pm 3.03 \%$ o $(2 \sigma)$. We find the best solution that approximates the May 2012 endmember when $\delta^{18} \mathrm{O}_{\mathrm{e}}=-7.7 \%$. Although we cannot precisely constrain the time taken to form the freshwater endmember, this calculation and the lack of evidence for $\delta^{18} \mathrm{O}_{\mathrm{p}}$ values of $-10 \%$ in the region suggest that evaporation as well as precipitation likely plays an important role in determining the $\delta^{18} \mathrm{O}_{\mathrm{sw}}$-salinity intercept in the central tropical Pacific.

\subsection{Paired $\delta^{18} O$ and $\delta D$ observations}

The relationship between $\delta{ }^{18} \mathrm{O}$ and $\delta \mathrm{D}$ values is a prominent feature of stable isotope studies of meteoric waters, providing insights into potential precipitation source regions and the effect of evaporation on rainfall and surface waters (Dansgaard, 1964; Rozanski et al., 1993; Gat, 1996). However, paired $\delta^{18} \mathrm{O}-\delta \mathrm{D}$ analyses of seawater are rare, although they may become more common with new CRDS technology (i.e., Munksgaard et al., 2012) and with the recent demonstration that paleosalinity estimates based on joint $\delta^{18} \mathrm{O}-\delta \mathrm{D}$ measurements proxies may reduce uncertainty and produce more quantitative paleosalinity reconstructions (LeGrande and Schmidt, 2011; Rohling, 2007). In Fig. 7 we compare precipitation and surface seawater $\delta^{18} \mathrm{O}-\delta \mathrm{D}$ data for the central tropical Pacific as a first-order assessment of $\delta^{18} \mathrm{O}-\delta \mathrm{D}$ variability in seawater from this region. Measured Kiritimati precipitation $\delta^{18} \mathrm{O}$ and $\delta \mathrm{D}$ values fall under the global meteoric water line. The low slope of the Kiritimati meteoric water line (5.1) and the low d-excess value $(1.4 \%$ ) from the monthly Kiritimati GNIP data indicate the influence of sub-cloud evaporation of rain in this region (Conroy et al., 2013; Gat, 1996). Corresponding values from the May 2012 daily rain samples (slope $=6.5$, d-excess $=6.0 \%$; Table 1 ) are higher than 
those derived from the GNIP data, but are consistent with an evaporative influence.

In central tropical Pacific seawaters, we find a significant correlation between $\delta^{18} \mathrm{O}$ and $\delta \mathrm{D}$ values of surface water $(\mathrm{r}=0.56, \mathrm{~N}=95$, $\mathrm{p}<0.001)$. The subsurface water has a relatively weaker, but still significant $\delta^{18} \mathrm{O}-\delta \mathrm{D}$ relationship $(\mathrm{r}=0.38, \mathrm{~N}=55, \mathrm{p}=0.004)$. There is no significant relationship between $\delta^{18} \mathrm{O}$ and $\delta \mathrm{D}$ in the deeper samples $(\mathrm{r}=-0.13, \mathrm{~N}=41, \mathrm{p}=0.41)$. We expect the strongest correlation in the surface waters, as surface forcing (precipitation and evaporation) imparts the surface seawater with its $\delta^{18} \mathrm{O}-\delta \mathrm{D}$ relationship. The slope of the $\delta^{18} \mathrm{O}-\delta \mathrm{D}$ relationship in surface water is 5.0, with an intercept of 0.8 (Fig. 7). The slope and intercept values of the central tropical Pacific 'surface seawater line' are distinctive from the typical meteoric water line (Gat, 1996; Rohling, 2007), as well as the global average $\delta^{18} \mathrm{O}-\delta \mathrm{D}$ seawater slope of 7.4 (Rohling, 2007). The May 2012 central tropical Pacific slope value of 5.0 likely indicates an evaporative influence in the region, consistent with low May $2012 \mathrm{P}$ - E values, and the influence of evaporation indicated from our analysis of the freshwater endmember (Craig and Gordon, 1965a,b; Rohling, 2007).

The surface slope and intercept of the Line Islands $\delta^{18} \mathrm{O}-\delta \mathrm{D}$ data are similar to the slope and intercept of the local MWL as derived from the monthly GNIP precipitation data (Fig. 7). At face value, this may suggest that mixing with local precipitation shapes the $\delta^{18} \mathrm{O}-\delta \mathrm{D}$ relationship in seawater. For example, Munksgaard et al. (2012) found that surface seawater $\delta^{18} \mathrm{O}-\delta \mathrm{D}$ values in the Great Barrier Reef Lagoon plotted on the same $\delta^{18} \mathrm{O}-\delta \mathrm{D}$ line as local river waters draining into the lagoon, indicating the $\delta^{18} \mathrm{O}-\delta \mathrm{D}$ relationship of surface waters of the Great Barrier Reef is at least partly controlled by the $\delta^{18} \mathrm{O}-\delta \mathrm{D}$ values of the freshwater endmember. However, analysis of the freshwater endmember in this study has highlighted the importance of evaporation. Thus, the similar $\delta^{18} \mathrm{O}-\delta \mathrm{D}$ slope and intercept of regional precipitation and surface seawater may indicate that evaporation imparts a strong influence on the stable isotopic composition of both rain and surface seawater in the central tropical Pacific.

\section{Conclusions}

We have added substantially to available $\delta^{18} \mathrm{O}_{\mathrm{sw}}$ data for the central tropical Pacific. These new data from May 2012 overlap earlier $\delta^{18} \mathrm{O}_{\mathrm{sw}}$ values and support the integrity of the new data measured with CRDS, and indicate that median values were not substantially biased by seasonal or interannual variability between Jan-Feb 1991 and May 2012. We find a strong $\delta^{18} \mathrm{O}_{\mathrm{sw}}$-salinity relationship in the surface and subsurface, and a consistent $\delta^{18} \mathrm{O}_{\mathrm{sw}}$-salinity relationship across the major currents and water masses of the central tropical Pacific.

The considerable overlap between the surface and subsurface $\delta^{18} \mathrm{O}_{\mathrm{sw}}$-salinity data highlights the important, yet poorly constrained role for vertical mixing in this region, as well as surface forcing and advection. More observational data and studies with isotope-equipped coupled climate models will be needed to better constrain this isotope budget. The increased amount of subsurface isotope data suggests complexities in the $\delta^{18} \mathrm{O}_{s w}$-salinity relationship: whereas salinity defines fresher Northern Hemisphere subsurface waters versus more saline equatorial/Southern Hemisphere subsurface waters, $\delta^{18} \mathrm{O}_{\mathrm{sw}}$ values are similar, at least in May 2012 versus Jan-Feb 1991. In addition, we find that while salinity has a large range across the EUC, which incorporates more saline Southern and less saline Northern Hemisphere waters, the $\delta^{18} \mathrm{O}_{\mathrm{sw}}$ standard deviation is not substantially higher relative to the other water masses. Thus, $\delta^{18} \mathrm{O}_{\mathrm{sw}}$ alone may not always constrain these subsurface water masses.

Surface spatial patterns indicate higher $\delta^{18} \mathrm{O}_{\mathrm{sw}}$ values extending further north in May 2012 relative to the data collected in the late 20th century. In addition, salinity values across the NECC region are higher than the May average. A weak NECC and negative precipitation anomaly may have driven higher salinity and $\delta^{18} \mathrm{O}_{s w}$ values in this region in May
2012, but more data are needed to quantify temporal variability in $\delta^{18} \mathrm{O}_{\text {sw. }}$

The surface freshwater endmember of the May $2012 \delta^{18} \mathrm{O}_{\mathrm{sw}}$-salinity curve differs appreciably from local precipitation $\delta^{18} \mathrm{O}$ values from the period of the cruise, as well as regional precipitation values derived from pre-existing data. In this region of strong advection and vertical mixing, constraining a freshwater endmember with a twoendmember mixing model may not be adequate. However, our analysis of the freshwater endmember, as well as the similarity in $\delta^{18} \mathrm{O}-\delta \mathrm{D}$ space between surface seawater and regional evaporation-influenced precipitation suggests a strong role for evaporation as well as precipitation in controlling stable water isotope values in the central tropical Pacific.

These data provide a valuable new addition to the modern seawater isotope dataset. Yet additional paired isotope-salinity time series are critically needed to assess variability in $\delta^{18} \mathrm{O}$-salinity slopes and intercepts, which likely vary through time. Temporal isotope-salinity datasets will also be useful for validation of model simulations of the isotope-salinity relationship. Ultimately, pairing modern as well as paleo-isotope data with such simulations will likely provide the best estimate of past ocean circulation and climate variability.

\section{Acknowledgments}

We thank the scientific party of MGL12-08 for seawater and rain sampling. We also thank Christopher Hintz for assistance with Kiritimati salinity measurements. This research was supported by NSF-AGS-PF 1049664 to JLC, NSF-ATM 0645291 to KMC and JLC, NSF-PECASE 0645291 to KMC and NSF-1159053 to JLS and PJP.

\section{References}

Abe, O., et al., 2009. A 6.5-year continuous record of sea surface salinity and seawater isotopic composition at Harbour of Ishigaki Island, southwest Japan. Isot. Environ. Health Stud. 45 (3), 247-258.

Adler, R.F., et al., 2003. The version-2 global precipitation climatology project (GPCP) monthly precipitation analysis (1979-present). J. Hydrometeorol. 4 (6), 1147-1167.

Alibert, C., McCulloch, M.T., 1997. Strontium/calcium ratios in modern Porites corals from the Great Barrier Reef as a proxy for sea surface temperature: calibration of the thermometer and monitoring of ENSO. Paleoceanography 12 (3), 345-363.

Beck, J.W., Recy, J., Taylor, F., Edwards, R.L., Cabioch, G., 1997. Abrupt changes in early Holocene tropical sea surface temperature derived from coral records. Nature 385 (6618), 705-707.

Behringer, D.W., Ji, M., Leetmaa, A., 1998. An improved coupled model for ENSO prediction and implications for ocean initialization. Part I: the Ocean Data Assimilation System. Mon. Weather Rev. 126 (4), 1013-1021.

Benway, H.M., Mix, A.C., 2004. Oxygen isotopes, upper-ocean salinity, and precipitation sources in the eastern tropical Pacific. Earth Planet. Sci. Lett. 224 (3-4), 493-507.

Bonjean, F., Lagerloef, G.S.E., 2002. Diagnostic model and analysis of the surface currents in the tropical Pacific Ocean. J. Phys. Oceanogr. 32 (10), 2938-2954.

Cobb, K.M., Charles, C.D., Cheng, H., Edwards, R.L., 2003. El Niño/Southern Oscillation and tropical Pacific climate during the last millennium. Nature 424 (6946), 271-276.

Cobb, K.M., et al., 2013. Highly variable El Nino-Southern Oscillation throughout the Holocene. Science 339 (6115), 67-70.

Cole, J.E., Dunbar, R.B., McClanahan, T.R., Muthiga, N.A., 2000. Tropical Pacific forcing of decadal SST variability in the western Indian Ocean over the past two centuries. Science 287 (5453), 617-619.

Conroy, J.L., Cobb, K.M., Noone, D., 2013. Comparison of precipitation isotope variability across the tropical Pacific in observations and SWING2 model simulations. J. Geophys. Res.-Atmos. 118, 1-26.

Correge, T., 2006. Sea surface temperature and salinity reconstruction from coral geochemical tracers. Palaeogeogr. Palaeoclimatol. Palaeoecol. 232 (2-4), 408-428.

Craig, H., Gordon, L.I., 1965a. Deuterium and oxygen 18 variations in the ocean and the marine atmosphere. In: Tongiorgi, E. (Ed.), Stable Isotopes in Oceanographic Studies and Paleotemperatures. Cons. Naz. di Rech, Spoleto, Italy, pp. 9-130.

Craig, H., Gordon, L.I., 1965b. Deuterium and oxygen 18 variations in the ocean and the marine environment. In: Tongiorgi, E. (Ed.), Stable Isotopes in Oceanographic Studies and Paleotempertures. Consiglio nazionale delle richerche, Spoleto, Italy, pp. 9-130.

Dansgaard, W., 1964. Stable isotopes in precipitation. Tellus 16 (4), 436-468.

Delaygue, G., et al., 2001. Oxygen isotope/salinity relationship in the northern Indian Ocean. Journal of Geophysical Research-Oceans 106 (C3), 4565-4574.

Dunbar, R.B., Wellington, G.M., Colgan, M.W., Glynn, P.W., 1994. Eastern Pacific SST since $1600 \mathrm{AD}$ the $\delta^{18} \mathrm{O}$ record of climate variability in Galápagos corals. Paleoceanography 9 (2), 291-315.

Elderfield, H., Ganssen, G., 2000. Past temperature and delta O-18 of surface ocean waters inferred from foraminiferal Mg/Ca ratios. Nature 405 (6785), 442-445.

Epstein, S., Mayeda, T., 1953. Variation of 018 content of waters from natural sources Geochimica Cosmochimica Acta 4, 213-224. 
Fairbanks, R.G., et al., 1997. Evaluating climate indices and their geochemical proxies measured in corals. Coral Reefs 16, S93-S100.

Gagan, M.K., et al., 1998. Temperature and surface-ocean water balance of the midHolocene tropical Western Pacific. Science 279 (5353), 1014-1018.

Gagan, M.K., et al., 2000. New views of tropical paleoclimates from corals. Quat. Sci. Rev. 19 (1-5), 45-64

Gat, J.R., 1996. Oxygen and hydrogen isotopes in the hydrologic cycle. Annu. Rev. Earth Planet. Sci. 24, 225-262.

Gonfiantini, R., 1986. Environmental isotopes in lake studies. In: Fritz, P., Fontes, J.-C. (Eds.), Handbook of Environmental Isotope Geochemistry, Vol. 2. The Terrestrial Environment. Elsevier, Amsterdam, pp. 113-168.

Hanawa, K., Talley, L.D., 2001. Mode waters. In: Siedler, G., Church, J. (Eds.), Ocean Circulation and Climtae. International Geophysics Series. Academic Press, pp. 373-386.

Hasson, A.E.A., Delcroix, T., Dussin, R., 2013. An assessment of the mixed layer salinity budget in the tropical Pacific Ocean. Observations and modelling (1990-2009). Ocean Dyn. 63 (2-3), 179-194.

IAEA/WMO, 2006. International Atomic Energy Agency/World Meteorological Organization Global Network for Isotopes in Precipitation. The GNIP Database (Accessible at: http://www.iaea.org/water).

Johnson, G.C., Sloyan, B.M., Kessler, W.S., McTaggart, K.E., 2002. Direct measurements of upper ocean currents and water properties across the tropical Pacific during the 1990s. Prog. Oceanogr. 52 (1), 31-61.

Johnson, G.C., Schmidtko, S., Lyman, J.M., 2012. Relative contributions of temperature and salinity to seasonal mixed layer density changes and horizontal density gradients. Journal of Geophysical Research-Oceans 117.

Koutavas, A., Joanides, S., 2012. El Nino-Southern Oscillation extrema in the Holocene and Last Glacial Maximum. Paleoceanography 27.

Koutavas, A., Lynch-Stieglitz, J., Marchitto, T.M., Sachs, J.P., 2002. El Niño-like pattern in ice age tropical Pacific sea surface temperature. Science 297 (5579), 226-230.

Laube-Le'Enfant, E., 1996. Global Seawater Oxygen-18 Database.

Lea, D.W., Mashiotta, T.A., Spero, H.J., 1999. Controls on magnesium and strontium uptake in planktonic foraminifera determined by live culturing. Geochimica Et Cosmochimica Acta 63 (16), 2369-2379.

Lea, D.W., Pak, D.K., Spero, H.J., 2000. Climate impact of late quaternary equatorial Pacific sea surface temperature variations. Science 289 (5485), 1719-1724.

Leech, P.J., Lynch-Stieglitz, J., Zhang, R., 2013. Western Pacific thermocline structure and the Pacific marine Intertropical Convergence Zone during the Last Glacial Maximum. Earth Planet. Sci. Lett. 363, 133-143.

LeGrande, A.N., Schmidt, G.A., 2006. Global gridded data set of the oxygen isotopic composition in seawater. Geophys. Res. Lett. 33 (12). http://dx.doi.org/10.1029/ 2006GL026011.

LeGrande, A.N., Schmidt, G.A., 2011. Water isotopologues as a quantitative paleosalinity proxy. Paleoceanography 26.

Liu, Z.G., Philander, S.G.H., Pacanowski, R.C., 1994. a gcm study of tropical-subtropical upper-ocean water exchange. J. Phys. Oceanogr. 24 (12), 2606-2623.

Majoube, M., 1971. Fractionnement en oxygene-18 et en deuterium entre l'eau et sa vapor. J. Chem. Phys. 197, 1423-1436.

Marin, F., et al., 2010. Annual reversal of the equatorial intermediate current in the Pacific: observations and model diagnostics. J. Phys. Oceanogr. 40 (5), 915-933.

McCreary, J.P., Lu, P., 1994. interaction between the subtropical and equatorial ocean circulations - the subtropical cell. J. Phys. Oceanogr. 24 (2), 466-497.

McGregor, H.V., et al., 2013. A weak El Niño/Southern Oscillation with delayed seasonal growth around 4,300 years ago. Nat. Geosci. http://dx.doi.org/10.1038/NGE01936.

Moerman, J.W., et al., 2013. Diurnal to interannual rainfall $\delta^{18} \mathrm{O}$ variations in northern Borneo driven by regional hydrology. Earth Planet. Sci. Lett. 369-370, 108-119.
Munksgaard, N.C., Wurster, C.M., Bass, A. Zagorskis, I, Bird, M., 2012. First continuous shipboard delta 0-18 and delta D measurements in sea water by diffusion sampling-cavity ring-down spectrometry. Environ. Chem. Lett. 10 (3), 301-307.

Nurhati, I.S., Cobb, K.M., Charles, C.D., Dunbar, R.B., 2009. Late 20th century warming and freshening in the central tropical Pacific. Geophys. Res. Lett. 36. http://dx.doi.org/ 10.1029/2009GL040270.

Nurhati, I.S., Cobb, K.M., Di Lorenzo, E., 2011. Decadal-scale SST and salinity variations in the central tropical Pacific: signatures of natural and anthropogenic climate change. J. Clim. 24 (13), 3294-3308.

Nurnberg, D., Bijma, J., Hemleben, C., 1996. Assessing the reliability of magnesium in foraminiferal calcite as a proxy for water mass temperatures (vol 60, pg 803, 1995). Geochimica Et Cosmochimica Acta 60 (13), 2483-2483.

Oppo, D.W., Schmidt, G.A., LeGrande, A.N., 2007. Seawater isotope constraints on tropical hydrology during the Holocene. Geophys. Res. Lett. 34 (13).

Oppo, D.W., Rosenthal, Y., Linsley, B.K., 2009. 2,000-year-long temperature and hydrology reconstructions from the Indo-Pacific warm pool. Nature 460 (7259), $1113-1116$

Ostlund, H.G., Craig, H., Broecker, W.S., Spenser, D., 1987. GEOSECS Atlantic, Pacific and Indian Ocean expeditions: shorebased data and graphics. Technical Report. National Science Foundation, Washington, D.C.

Peterson, T.C., Vose, R.S., 1997. An overview of the Global Historical Climatology Network temperature database. Bull. Am. Meteorol. Soc. 78 (12), 2837-2849.

Rohling, E.J., 2007. Progress in paleosalinity: overview and presentation of a new approach. Paleoceanography 22 (3).

Rozanski, K., Araguas-Araguas, L., Gonfiantini, R., 1993. Isotopic patterns in modern global precipitation. In: Swart, P.K. (Ed.), Climate Change in Continental Isotopic Records. American Geophysical Union, Washington, DC, pp. 1-36.

Sayani, H.R., et al., 2011. Effects of diagenesis on paleoclimate reconstructions from modern and young fossil corals. Geochimica Et Cosmochimica Acta 75 (21), 6361-6373.

Schmidt, G.A., 1999. Forward modeling of carbonate proxy data from planktonic foraminifera using oxygen isotope tracers in a global ocean model. Paleoceanography 14 (4), 482-497.

Schmidt, G.A., Bigg, G.R., Rohling, E.J., 1999. Global Seawater Oxygen-18 Database. (http://data.giss.nasa.gov/o18data/).

Schmidt, G.A., LeGrande, A.N., Hoffmann, G., 2007. Water isotope expressions of intrinsic and forced variability in a coupled ocean-atmosphere model. J. Geophys. Res.-Atmos. 112 (D10)

Smith, T.M., Reynolds, R.W., Peterson, T.C., Lawrimore, J., 2008. Improvements to NOAA's historical merged land-ocean surface temperature analysis (1880-2006). J. Clim. 21 (10), 2283-2296.

Stott, L., Poulsen, C., Lund, S., Thunell, R., 2002. Super ENSO and global climate oscillations at millennial time scales. Science 297 (5579), 222-226.

Thompson, D.M., Ault, T.R., Evans, M.N., Cole, J.E., Emile-Geay, J., 2011. Comparison of observed and simulated tropical climate trends using a forward model of coral d(18)O. Geophys. Res. Lett. 38. http://dx.doi.org/10.1029/2011gl048224.

Toggweiler, J.R., Dixon, K., 1991. The Peru upwelling and the ventiliation of the south Pacific thermocline. J. Geophys. Res. 96 (C11), 20467-20497.

Tsuchiya, M., Lukas, R., Fine, R.A., Firing, E., Lindstom, E., 1990. Source waters of the Pacific equatorial undercurrent. Progress in Occeanography 23, 101-147.

Tudhope, A.W., et al., 2001. Variability in the El Niño-Southern oscillation through a glacial-interglacial cycle. Science 291 (5508), 1511-1517.

Yu, L.S., Weller, R.A., 2007. Objectively analyzed air-sea heat fluxes for the global ice-free oceans (1981-2005). Bull. Am. Meteorol. Soc. 88 (4), 527-+. 